\title{
A novel xylan degrading $\beta$-D-xylosidase: purification and biochemical characterization
}

\author{
Michele Michelin • Simone C. Peixoto-Nogueira • \\ Tony M. Silva $\cdot$ João A. Jorge $\cdot$ Héctor F. Terenzi \\ José A. Teixeira $\cdot$ Maria de Lourdes T. M. Polizeli
}

Received: 9 September 2011 / Accepted: 6 July 2012 / Published online: 25 July 2012

(C) Springer Science+Business Media B.V. 2012

\begin{abstract}
Aspergillus ochraceus, a thermotolerant fungus isolated in Brazil from decomposing materials, produced an extracellular $\beta$-xylosidase that was purified using DEAE-cellulose ion exchange chromatography, Sephadex G-100 and Biogel P-60 gel filtration. $\beta$-xylosidase is a glycoprotein (39\% carbohydrate content) and has a molecular mass of $137 \mathrm{kDa}$ by SDS-PAGE, with optimal temperature and $\mathrm{pH}$ at $70{ }^{\circ} \mathrm{C}$ and $3.0-5.5$, respectively. $\beta$-xylosidase was stable in acidic $\mathrm{pH}(3.0-6.0)$ and $70{ }^{\circ} \mathrm{C}$ for $1 \mathrm{~h}$. The enzyme was activated by $5 \mathrm{mM} \mathrm{MnCl}_{2}(28 \%)$ and $\mathrm{MgCl}_{2}(20 \%)$ salts. The $\beta$-xylosidase produced by A. ochraceus preferentially hydrolyzed $p$-nitrophenyl- $\beta$ D-xylopyranoside, exhibiting apparent $\mathrm{K}_{\mathrm{m}}$ and $\mathrm{V}_{\max }$ values of $0.66 \mathrm{mM}$ and $39 \mathrm{U}$ (mg protein) ${ }^{-1}$ respectively, and to a lesser extent $p$-nitrophenyl- $\beta$-D-glucopyranoside. The enzyme was able to hydrolyze xylan from different sources, suggesting a novel $\beta$-D-xylosidase that degrades xylan. HPLC analysis revealed xylans of different compositions which allowed explaining the differences in specificity observed by $\beta$-xylosidase. TLC confirmed the capacity
\end{abstract}

\footnotetext{
M. Michelin - T. M. Silva - J. A. Jorge ·

H. F. Terenzi · M. de Lourdes T. M. Polizeli ( $\square)$

Departamento de Biologia, Faculdade de Filosofia, Ciências e Letras de Ribeirão Preto, Universidade de São Paulo, Avenida Bandeirantes 3900, Ribeirão Preto, SP 14040-901, Brazil

e-mail: polizeli@ffclrp.usp.br
}

M. Michelin · J. A. Teixeira

Departamento de Engenharia Biológica, Universidade do Minho, Campus Gualtar, 4710-057 Braga, Portugal

S. C. Peixoto-Nogueira · M. de Lourdes T. M. Polizeli Departamento de Bioquímica e Imunologia, Faculdade de Medicina de Ribeirão Preto, Universidade de São Paulo, Avenida Bandeirantes 3900, Ribeirão Preto, SP 14040-901, Brazil of the enzyme in hydrolyzing xylan and larger xylooligosaccharides, as xylopentaose.

Keywords Aspergillus ochraceus $\cdot \beta$-xylosidase . Purification · Xylan

\section{Introduction}

$\beta-1,4$-xylan is the major hemicellulose component of the lignocellulosic biomass (Eriksson and Wood 1985; Polizeli et al. 2005; Polizeli 2009). It is formed by a backbone of $\beta$-1,4-linked-D-xylopyranosyl residues, and different substitute groups in the side chains. Several enzymes are required for the hydrolysis of xylan to xylo-oligosaccharides, including $\beta$-D-xylanase (1,4- $\beta$-D-xylan xylanohydrolase, EC 3.2.1.8) and $\beta$-xylosidase (1,4- $\beta$-D-xylan xylohydrolase, EC 3.2.1.37). Xylanases cleave internal xylosidic linkages producing xylo-oligosaccharides, while $\beta$-xylosidases hydrolyze xylo-oligosaccharides and xylobiose releasing xylose (Wong et al. 1988; Sunna and Antranikian 1997).

According to Biely $(1985,1993), \beta$-D-xylosidases can be recognized and classified as xylobiases and exo-1,4- $\beta$ xylanases in relation to their relative affinities for xylobiose and larger xylo-oligosaccharides, respectively. However, recent works suggest that $\beta$-xylosidases can be defined as enzymes that catalyze the cleavage of xylobiose and attack the non-reducing ends of short xylo-oligosaccharides to release xylose (Rasmussem et al. 2006; Knob et al. 2010). Besides, most of the purified $\beta$-xylosidases are not able to degrade xylans (Knob et al. 2010).

$\beta$-xylosidases are essential enzymes of the microbial xylanolytic system, and contribute to decrease the inhibition of xylanases by the end-product of xylan hydrolysis 
(Poutanen and Puls 1988; Guerfali et al. 2008). This enzyme is cell-associated in most bacteria and yeast, but it is freely found in the culture media of some fungi (Guerfali et al. 2008; Saha and Bothast 1999).

Growing interest on the bioconversion of hemicellulose has recently arisen, as a consequence of its potential application in several agro-industrial processes. These include the conversion of hemicellulose materials to fuels and chemicals, paper-pulp delignification, improvement of beer consistency, improved digestibility of animal feedstocks and clarification of juices (Zamost et al. 1991; Viikari et al. 1994; Kulkarni et al. 1999; Saha 2003a; Zanoelo et al. 2004).

The present study reports the purification and biochemical characterization of a $\beta$-xylosidase produced by an isolate of Aspergillus ochraceus. This fungus is a good producer of xylanolytic enzymes and relevant studies related to the $\beta$-D-xylanase production have been published by the group (Betini et al. 2009; Michelin et al. 2010). Besides, this strain has the advantageous characteristics as the secretion of high levels of thermostable $\beta$ xylosidase in the presence of xylan as carbon source, which is able to hydrolyze xylans of various origins and, therefore, with differences of structures and solubility.

\section{Materials and methods}

Microorganism and culture conditions

Aspergillus ochraceus was isolated from decomposing fruit and leafs, in the Ribeirão Preto region-São Paulo, Brazil. This strain was identified and deposited as A. ochraceus at the certified Mycology Culture Collection URM at Federal University of Pernambuco (Recife, Brazil, number 604). Stock culture was propagated at $30^{\circ} \mathrm{C}$ on slants of solid $4 \%$ (w/v) PDA (Biolife ${ }^{\circledR}$ ) medium and stored at $4{ }^{\circ} \mathrm{C}$.

Growth and enzyme production were followed by a twostage procedure. Conidia from 7 day-old cultures, with a concentration of $2 \times 10^{7}$ spores $\mathrm{ml}^{-1}$, were inoculated into $250 \mathrm{ml}$ Erlenmeyer flasks containing $50 \mathrm{ml}$ of the liquid medium described by Rizzatti et al. (2001) with $1 \%$ (w/v) glucose as carbon source. The cultures were incubated at $30{ }^{\circ} \mathrm{C}$, without agitation, for $72 \mathrm{~h}$. The mycelial mass was transferred to $250 \mathrm{ml}$ Erlenmeyer flasks containing $50 \mathrm{ml}$ of Czapeck medium (Wiseman 1975) with $1 \%$ (w/v) oat spelt xylan $\left(\operatorname{Sigma}^{\circledR}\right)$ as carbon source and incubated at $30{ }^{\circ} \mathrm{C}$, under $100 \mathrm{rpm}$ agitation, for $72 \mathrm{~h}$.

Enzymatic assays and protein determination

$\beta$-Xylosidase activity was determined by incubating $200 \mu \mathrm{l}$ of enzyme sample with $50 \mu \mathrm{l}$ of $0.92 \mathrm{mM} p$-nitrophenyl- $\beta$-D- xylopyranoside (PNP-xyl) substrate, and $150 \mu \mathrm{l}$ of $0.15 \mathrm{M}$ citrate-phosphate buffer $(\mathrm{pH} 4.5)$ at $70{ }^{\circ} \mathrm{C}$ for $10 \mathrm{~min}$. The reaction was stopped by adding $1 \mathrm{ml}$ of sodium tetraborate saturated solution, and the $p$-nitrophenol released from the substrate was measured by spectrophotometer at $405 \mathrm{~nm}$. One unit of $\beta$-D-xylosidase activity was defined as the amount of enzyme that releases $1 \mu \mathrm{mol}$ of $p$-nitrophenol per minute. Specific activity was defined as enzyme units per milligram protein. Other aryl- $\beta$-glycosidase activities were assayed with the appropriate substrates ( $p$-nitrophenyl- $\beta$-D-glucopyranoside; $p$-nitrophenyl- $\beta$-D-arabinopyranoside; $p$-nitrophenyl- $\beta$ D-galactopyranoside; $p$-nitrophenyl- $\beta$-D-cellobiopyranoside; 4-O-methyl-D-glucurono-D-xylan and 4-nitrophenyl-acetate) under the same conditions described for PNP-xyl.

Regarding $\beta$-xylosidase activity against natural substrates (xylobiose and some xylans), the assays were performed by incubating $200 \mu \mathrm{l}$ of the pure enzyme sample with $200 \mu \mathrm{l}$ of $1 \mathrm{mg} / \mathrm{ml}$ substrate in $0.15 \mathrm{M}$ citratephosphate buffer ( $\mathrm{pH} 4.5)$ at $70{ }^{\circ} \mathrm{C}$ for $20 \mathrm{~min}$. Releasing sugars were estimated with $3^{\prime}, 5^{\prime}$ dinitrosalicylic acid (DNS) and measured by spectrophotometer at $540 \mathrm{~nm}$ (Miller 1959). One unit of $\beta$-xylosidase activity was defined as the amount of enzyme that releases $1 \mu \mathrm{mol}$ reducing sugar equivalent to xylose per minute. Protein concentration was estimated as described by Lowry et al. (1951) using bovine serum albumin as standard.

Purification of extracellular $\beta$-xylosidase

\section{DEAE-cellulose chromatography column}

All procedures of purification were performed at $4{ }^{\circ} \mathrm{C}$. The enzyme extract $(160 \mathrm{ml})$ was dialyzed against $0.15 \mathrm{M}$ citrate-phosphate buffer in semi-permeable cellulose membrane tubing in order to remove salts and smaller molecules. After that, the dialyzed sample was applied on a DEAE-cellulose column $(1.9 \times 9 \mathrm{~cm})$ pre-equilibrated with a $10 \mathrm{mM}$ Tris- $\mathrm{HCl}$ buffer ( $\mathrm{pH}$ 7.5). The column was extensively washed with this buffer and $\beta$-xylosidase was eluted with $200 \mathrm{ml}$ of a gradient of $0-1.5 \mathrm{M} \mathrm{NaCl}$ in same buffer. Fractions of $2.5 \mathrm{ml}$ were collected and the peak containing $\beta$-xylosidase activity was pooled, dialyzed overnight against distilled water, lyophilized and suspended in $2 \mathrm{ml}$ of $100 \mathrm{mM}$ sodium acetate buffer, $\mathrm{pH} 5.5$, plus $150 \mathrm{mM}$ sodium chloride.

\section{Sephadex G-100 chromatography column}

The concentrated active $\beta$-xylosidase fractions obtained from the ion exchanger column $(2 \mathrm{ml})$ were applied to a Sephadex G-100 gel filtration column $(1.5 \times 57 \mathrm{~cm})$ at $4{ }^{\circ} \mathrm{C}$. The column was equilibrated and eluted with the same buffer used to suspend the sample $(100 \mathrm{mM}$ sodium 
acetate buffer, $\mathrm{pH} 5.5$, plus $150 \mathrm{mM}$ sodium chloride). Fractions of $1.2 \mathrm{ml}$ were collected and the active fractions were pooled, dialyzed against distilled water, lyophilized and suspended in $1 \mathrm{ml}$ of $100 \mathrm{mM}$ sodium acetate buffer, $\mathrm{pH} 5.5$.

\section{Biogel P-60 chromatography column}

Concentrated enzyme $(1 \mathrm{ml})$ was applied to a Biogel P-60 gel filtration column $(1.2 \times 45 \mathrm{~cm})$ equilibrated and eluted with $100 \mathrm{mM}$ sodium acetate buffer, $\mathrm{pH}$ 5.5, and the active fractions were pooled and used for enzyme characterization. The proteins were quantified by measuring the absorbance at $280 \mathrm{~nm}$. The procedure was carried out at $4{ }^{\circ} \mathrm{C}$ and fractions of $1.0 \mathrm{ml}$ were collected.

Polyacrylamide gel electrophoresis and carbohydrate content

Electrophoresis under non-denaturing conditions was carried out by the method of Davis (1964), using $6 \%$ acrylamide. SDS-PAGE (7\%) was carried out according to the method of Laemmli (1970), using myosin (205 kDa); phosphorylase b (97.4 kDa); bovine serum albumin (66 kDa); egg albumin (45 kDa); carbonic anhydrase $(29 \mathrm{kDa})$ as molecular mass standards (Sigma). After the runs, the gels were stained with Comassie Brilliant Blue.

Total neutral carbohydrate was estimated by the method of Dubois et al. (1956), using D-mannose as standard.

\section{Kinetic parameters}

Kinetic parameters $\left(\mathrm{K}_{\mathrm{m}}\right.$ and $\left.\mathrm{V}_{\max }\right)$ were determined by incubating the enzyme under optimal conditions of temperature and $\mathrm{pH}$, with different concentrations of $p$-NP-xyl (0.092-9.2 mM). The values of Michaelis constant were calculated from Lineweaver-Burk plots (1934).

\section{Chromatography of hydrolysis products}

Thin layer chromatography (TLC silica gel plates, DCAlufolien Kieselgel 60, Merck) was performed using the methodology described by Fontana et al. (1988). A volume of $5 \mu \mathrm{l}$ of the compounds formed by the action of $50 \mu \mathrm{l}$ pure $\beta$-D-xylosidase on $50 \mu \mathrm{l}$ of substrate in $0.15 \mathrm{M}$ citrate-phosphate buffer $(\mathrm{pH} 4.5)$ at $70{ }^{\circ} \mathrm{C}$ were applied on silica gel plates, and subjected to two sequential ascending chromatography runs using butanol:ethanol:water $(5: 3: 2$ by vol) as solvent system. After air-drying the plate, the spots were detected by spraying with concentrated $\mathrm{H}_{2} \mathrm{SO}_{4}$ and methanol $(1: 9 \mathrm{v} / \mathrm{v})$ containing $0.2 \%(\mathrm{w} / \mathrm{v})$ orcinol, followed by heating at $100{ }^{\circ} \mathrm{C}$.
The substrates used were $1 \%(\mathrm{w} / \mathrm{v})$ birchwood xylan and xylo-oligosaccharides obtained by the action of a purified endo-xylanase from A. ochraceus on $1 \%(\mathrm{w} / \mathrm{v})$ birchwood xylan after 30 min of reaction.

Chemical composition of the xylans

The chemical composition of the xylans was performed following the procedure reported by Ruzene et al. (2008). Samples of $0.25 \mathrm{~g}$ of birchwood xylan, oat spelt xylan and eucalyptus xylan were treated with $2.5 \mathrm{ml}$ of $72 \%(\mathrm{w} / \mathrm{w})$ $\mathrm{H}_{2} \mathrm{SO}_{4}$ under stirring at $30^{\circ} \mathrm{C}$ for $1 \mathrm{~h}$. The reaction was interrupted by adding $74.3 \mathrm{ml}$ of distilled water and the mixtures were then transferred to $250 \mathrm{ml}$ Erlenmeyer flasks. The flasks were autoclaved for $1 \mathrm{~h}$ at $121{ }^{\circ} \mathrm{C}$ for the complete hydrolysis of oligomers. The mixtures were filtered and the hydrolysates were analyzed by HPLC. A MetaCarb $87 \mathrm{P}(300 \times 7.8 \mathrm{~mm}$, Varian, USA $)$ column was used to the analysis of the sugars-glucose, xylose, galactose, arabinose and mannose-under the following conditions: $80^{\circ} \mathrm{C}$, ultrapure water on mobile phase, flow rate $0.4 \mathrm{ml} / \mathrm{min}$. The analysis of the acetic acid and galacturonic acid contents were performed using a Metacarb $87 \mathrm{H}$ column $(300 \times 7.8 \mathrm{~mm}$, Varian, USA $)$ at $60{ }^{\circ} \mathrm{C}$, with $0.005 \mathrm{~mol} / 1 \mathrm{H}_{2} \mathrm{SO}_{4}$ as mobile phase and flow rate $0.6 \mathrm{ml} / \mathrm{min}$ coupled at Jasco chromatograph with refraction-index and ultraviolet detectors. Sugars and acids concentrations were determined from calibration curves of pure compounds.

\section{Results and discussion}

Purification of extracellular $\beta$-D-xylosidase

$\beta$-D-Xylosidase was purified after three chromatography steps detailed in Materials and methods. Figure 1a illustrates the elution profile of the dialyzed culture filtrate from A. ochraceus on DEAE-cellulose column, in which a single peak containing $\beta$-xylosidase activity was retained by the resin and eluted at approximately $0.7 \mathrm{M}$ of a $\mathrm{NaCl}$ linear gradient. The fractions containing $\beta$-xylosidase activity were applied to Sephadex G-100 column (Fig. 1b), where major contaminants were separated. After that, the fractions with $\beta$-xylosidase activity were applied to Biogel P-60 filtration column (Fig. 1c), resulting in a 22-fold purification and a recovery of $7.17 \%$. A summary of the purification procedures is presented in Table 1. In this table can also be observed the enzyme concentration used in the experiments of biochemical characterization. The purification protocol resulted in a pure enzyme that migrated as a single band on polyacrylamide gel electrophoresis (PAGE; Fig. 2-lane a). 

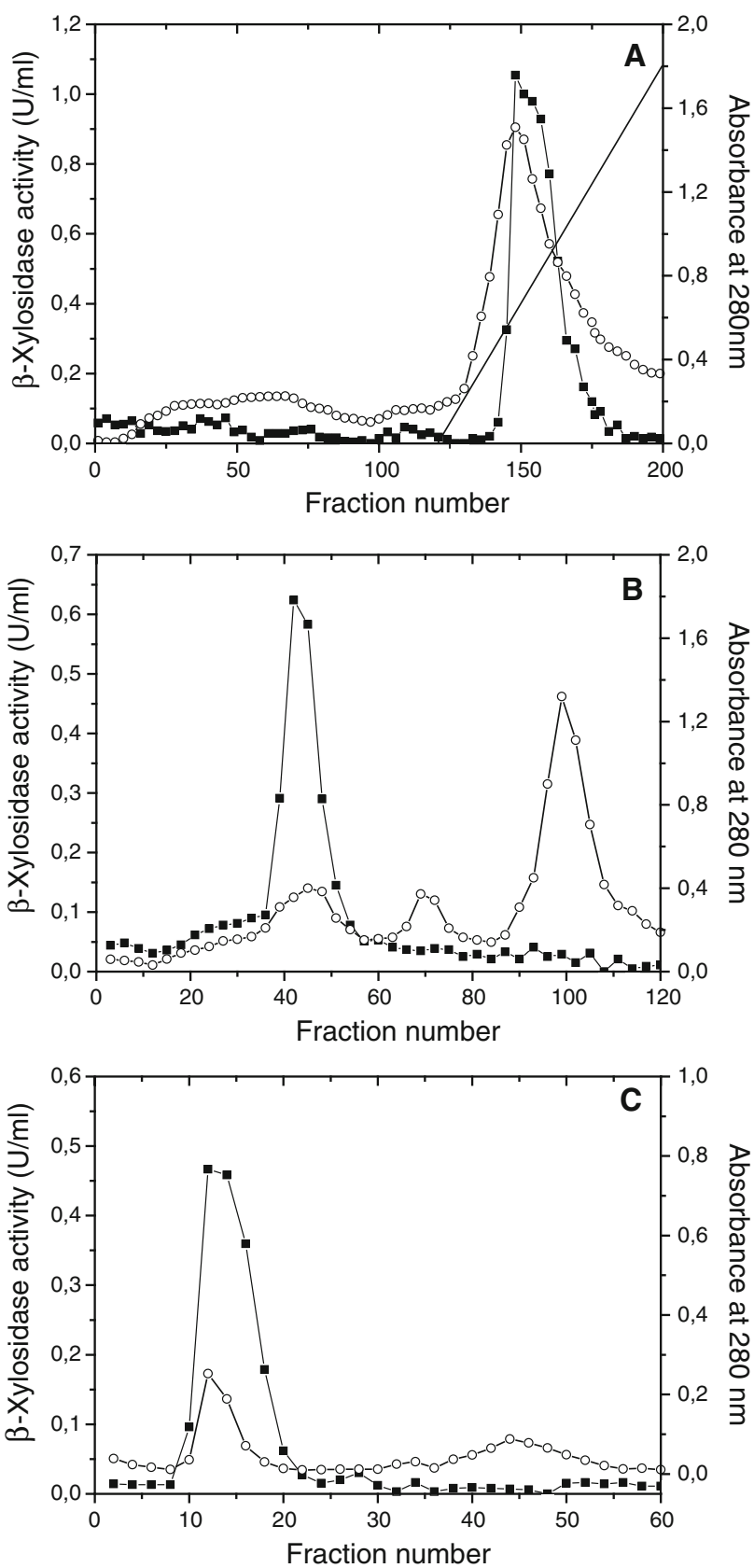

Fig. 1 Elution profile of the $\beta$-xylosidase activity from DEAEcellulose (a), Sephadex G-100 (b) and Biogel P-60 (c) chromatography columns. Symbols: (filled square) $\beta$-xylosidase activity; (open circle) absorbance $280 \mathrm{~nm}$; (slashed line) linear gradient of sodium chloride $(0-1.5 \mathrm{M})$. The enzyme activity was determined at $70{ }^{\circ} \mathrm{C}$ and $\mathrm{pH}$ 4.5. More details in "Materials and methods" section

Determination of $\mathrm{M}_{\mathrm{r}}$ and carbohydrate content

The molecular mass of the purified $\beta$-xylosidase was estimated as $137 \mathrm{kDa}$ by SDS-PAGE (Fig. 2-lane b). Most of the purified $\beta$-D-xylosidases exhibit molecular masses above $100 \mathrm{kDa}$ (Sunna and Antranikian 1997).
Table 1 Summary of the purification steps of the extracellular $\beta$-xylosidase by $A$. ochraceus

\begin{tabular}{|c|c|c|c|c|c|}
\hline $\begin{array}{l}\text { Purification } \\
\text { steps }\end{array}$ & $\begin{array}{l}\text { Protein } \\
\text { (total } \\
\text { mg) }\end{array}$ & $\begin{array}{l}\text { Activity } \\
\text { (total } \\
\text { U) }\end{array}$ & $\begin{array}{l}\text { Specific } \\
\text { activity } \\
(\mathrm{U} \text { mg } \\
\left.\text { protein }^{-1}\right)\end{array}$ & $\begin{array}{l}\text { Yield } \\
(\%)\end{array}$ & $\begin{array}{l}\text { Purification } \\
\text { (-fold) }\end{array}$ \\
\hline $\begin{array}{l}\text { Crude } \\
\text { extract }\end{array}$ & 107.50 & 202.25 & 1.88 & 100.00 & 1.00 \\
\hline $\begin{array}{l}\text { Filtrate } \\
\text { dialyzed }\end{array}$ & 75.00 & 233.00 & 3.11 & 115.20 & 1.65 \\
\hline $\begin{array}{l}\text { DEAE- } \\
\text { cellulose }\end{array}$ & 26.25 & 109.75 & 4.18 & 54.26 & 2.22 \\
\hline $\begin{array}{c}\text { Sephadex } \\
\text { G-100 }\end{array}$ & 3.20 & 33.50 & 10.47 & 16.56 & 5.57 \\
\hline Biogel P-60 & 0.35 & 14.50 & 41.43 & 7.17 & 22.04 \\
\hline
\end{tabular}

The enzyme activity was determined at $70{ }^{\circ} \mathrm{C}$ and $\mathrm{pH} 4.5$

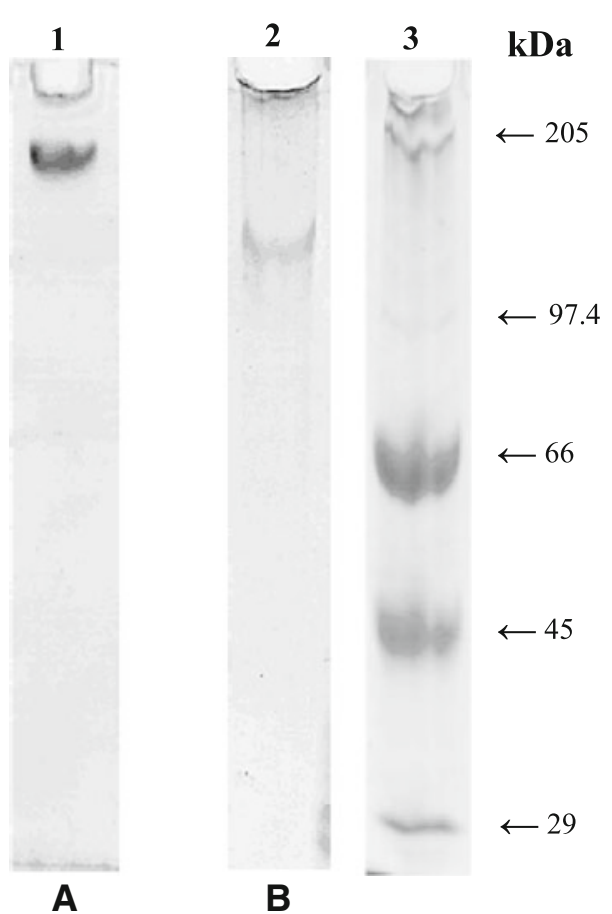

Fig. 2 PAGE (a) and SDS-PAGE (b) of the A. ochraceus purified $\beta$ D-xylosidase. Lane 1 and 2: purified $\beta$-xylosidase. Lane 3: molecular mass markers (myosin $205 \mathrm{kDA}$; phosphorylase b $97.4 \mathrm{kDa}$; bovine albumin $66 \mathrm{kDa}$; egg albumin $45 \mathrm{kDa}$ and carbonic anhydrase $29 \mathrm{kDa})$

The A. ochraceus $\beta$-xylosidase is a glycoprotein that contains $39 \%$ carbohydrate, which is in agreement with other fungal $\beta$-xylosidases described in the literature (Rizzatti et al. 2001; Herrmann et al. 1997; Wakiyama et al. 2008). 

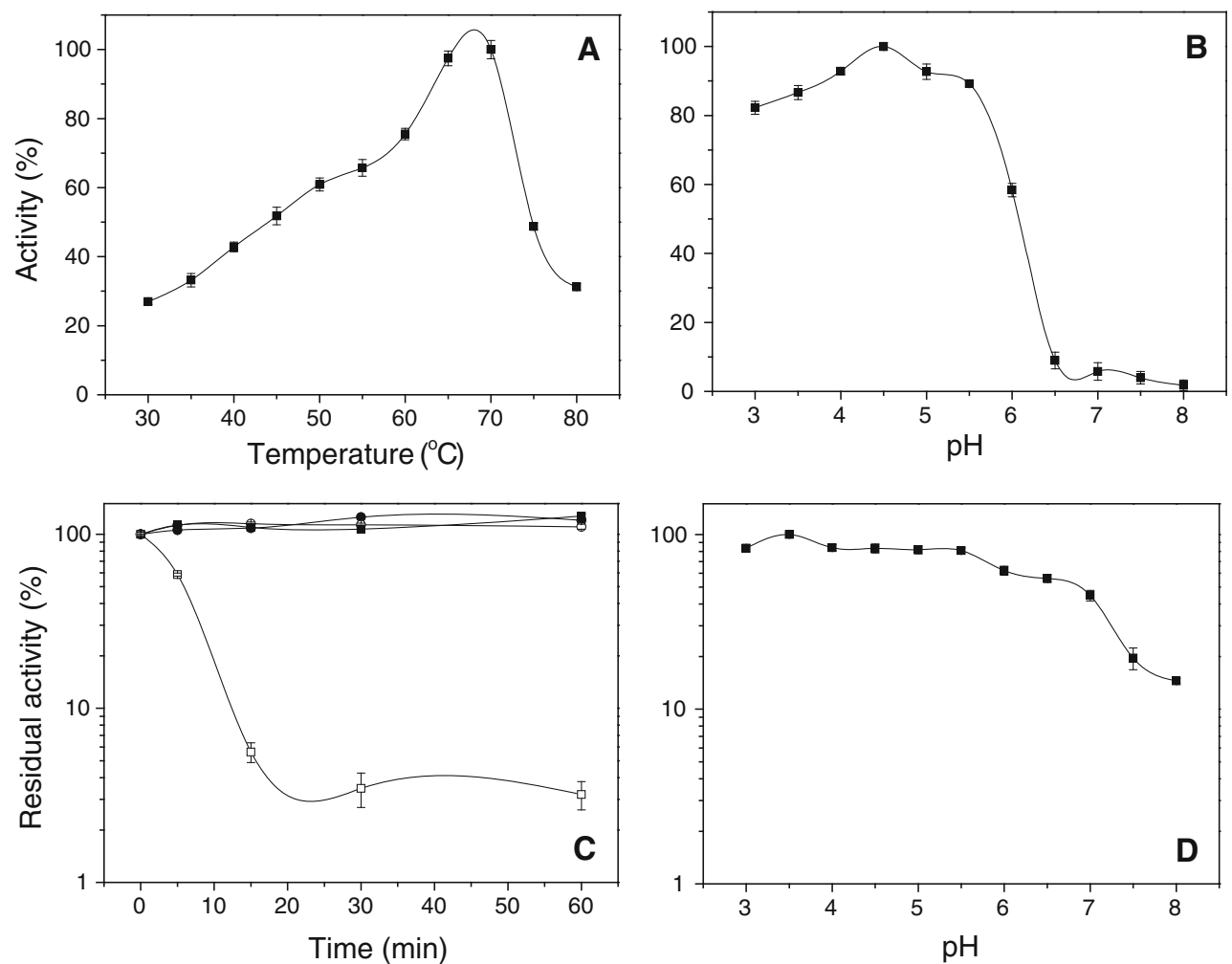

Fig. 3 Effect of temperature and $\mathrm{pH}$ on purified $\beta$-xylosidase activity. Temperature (a) and $\mathrm{pH}$ (b) optimal; thermostability at $60{ }^{\circ} \mathrm{C}$ (filled circle), $65^{\circ} \mathrm{C}$ (open circle), $70{ }^{\circ} \mathrm{C}$ (filled square) and $75{ }^{\circ} \mathrm{C}$ (open square) (c); and $\mathrm{pH}$ stability for $1 \mathrm{~h}$ at $4{ }^{\circ} \mathrm{C}(\mathbf{d})$. The $\beta$ -

xylosidase activity was determined by discontinuous methods using $0.25 \%(\mathrm{w} / \mathrm{v})$ of the PNF-xylopyranoside synthetic substrate as described in "Materials and methods"

Effect of temperature and $\mathrm{pH}$ on enzyme activity and stability

Figure $3 \mathrm{a}$ and $\mathrm{b}$ illustrate the influence that temperature and $\mathrm{pH}$ had on $\beta$-xylosidase activity, respectively. The enzyme showed an optimum of activity at $70{ }^{\circ} \mathrm{C}$ and in a $\mathrm{pH}$ range of 3.0-5.5 (up to $80 \%$ activity). Both, temperature and $\mathrm{pH}$ optima were similar to those reported for the $\beta$-xylosidase of Aspergillus japonicus (Wakiyama et al. 2008), Trichoderma harzianum (Ximenes et al. 1996), Aspergillus awamori K4 (Kurakabe et al. 1997) and Aspergillus fumigatus (Lenartovicz et al. 2003).

The effect of temperature on the stability of the enzyme was also examined. The purified enzyme was completely stable for $1 \mathrm{~h}$ at $70{ }^{\circ} \mathrm{C}$, and decayed with a half-life of approximately $6 \mathrm{~min}$ at $75{ }^{\circ} \mathrm{C}$ (Fig. 3c). Studies of the thermal stability indicated that the purified A. ochraceus $\beta$ xylosidase was more stable than the fungal $\beta$-xylosidase from A. phoenicis (Rizzatti et al. 2001) and A. japonicus (Wakiyama et al. 2008). Stability and activity at high temperatures are desirable properties in this type of enzyme, considering the fact that most industrial processes where xylanolytic enzymes can be useful are carried out at high temperatures (Wong and Saddler 1993; Knob et al.

2010). The enzyme was stable (in a range of $\mathrm{pH}$ of 3.0-6.0) at $\mathrm{pH}$ values between 3.0 and 6.0 for $1 \mathrm{~h}$ at $4{ }^{\circ} \mathrm{C}$ (Fig. $3 \mathrm{~d}$ ). This $\mathrm{pH}$ range was similar to $A$. phoenicis $\beta$-xylosidase (Rizzatti et al. 2001) but differed to the $\beta$-xylosidase of Talaromyces thermophilus (Guerfali et al. 2008) that was more stable when $\mathrm{pH}$ was higher than 5.0.

Influence of salts, EDTA and $\beta$-mercaptoethanol on the $\beta$-xylosidase activity

The effects of several chloride salts and other reagents on the $\beta$-xylosidase activity are shown in Table 2 . The results demonstrated a slight stimulation by $5 \mathrm{mM} \mathrm{MnCl} 2(28 \%)$ and $\mathrm{MgCl}_{2},(20 \%)$ and an inhibitory effect by high concentrations $(10 \mathrm{mM})$ of the same compounds. 2-mercaptoethanol is a reducing agent that can modify the tertiary structure of the enzyme and affect the enzymatic activity, and for A. ochraceus $\beta$-xylosidase, it was observed $14 \%$ activation using $5 \mathrm{mM}$ of these compound. The enzyme activity was drastically inhibited by sulfhydryl oxidant metal $\left(\mathrm{Hg}^{2+}\right)$, suggesting the existence of thiol groups at the active site of the enzyme (Sandrim et al. 2005). High inhibition was also observed in the presence of $10 \mathrm{mM}$ $\mathrm{CoCl}_{2}, \mathrm{NaCl}$ and $\mathrm{NH}_{4} \mathrm{Cl}$. EDTA did not significantly affect 
Table 2 Influence of salts, EDTA and 2-mercaptoethanol on $\beta$-xylosidase activity

\begin{tabular}{lrrr}
\hline Reagents & \multicolumn{3}{l}{ Activity $(\%)$} \\
\cline { 2 - 4 } & \multicolumn{1}{c}{$1 \mathrm{mM}$} & \multicolumn{1}{c}{$5 \mathrm{mM}$} & $10 \mathrm{mM}$ \\
\hline None & 100.00 & 100.00 & 100.00 \\
$\mathrm{NH}_{4} \mathrm{Cl}$ & $84.06( \pm 0.15)$ & $88.18( \pm 0.15)$ & $37.24( \pm 0.11)$ \\
$\mathrm{HgCl}$ & $1.42( \pm 0.10)$ & $1.80( \pm 0.13)$ & $10.70( \pm 0.10)$ \\
$\mathrm{NaCl}$ & $77.21( \pm 0.11)$ & $40.08( \pm 0.19)$ & $35.19( \pm 0.17)$ \\
$\mathrm{CoCl}_{2} \cdot 6 \mathrm{H}_{2} \mathrm{O}$ & $93.74( \pm 0.19)$ & $105.01( \pm 0.20)$ & $24.07( \pm 0.22)$ \\
$\mathrm{MnCl}_{2} \cdot 4 \mathrm{H}_{2} \mathrm{O}$ & $102.81( \pm 0.20)$ & $128.46( \pm 0.28)$ & $62.76( \pm 0.25)$ \\
$\mathrm{MgCl}_{2} \cdot 6 \mathrm{H}_{2} \mathrm{O}$ & $102.24( \pm 0.21)$ & $120.04( \pm 0.25)$ & $83.54( \pm 0.19)$ \\
$\mathrm{CaCl}_{2}$ & $98.54( \pm 0.16)$ & $94.16( \pm 0.17)$ & $91.97( \pm 0.23)$ \\
$\mathrm{KCl}$ & $98.54( \pm 0.22)$ & $100.00( \pm 0.14)$ & $97.08( \pm 0.15)$ \\
EDTA & $104.38( \pm 0.12)$ & $97.81( \pm 0.19)$ & $99.27( \pm 0.18)$ \\
2-mercaptoethanol & $91.54( \pm 0.25)$ & $114.23( \pm 0.13)$ & $104.12( \pm 0.15)$ \\
\hline
\end{tabular}

The assays were performed at $70{ }^{\circ} \mathrm{C}$ and $\mathrm{pH} 4.5$

this activity, suggesting that metal ions were not required for enzyme activity.

Substrate hydrolysis

The purified enzyme hydrolyzed mainly PNP-xylopyranoside and PNP-glucopyranoside, and to some extent, also hydrolysed PNP-arabinopyranoside, PNP-galactopyranoside and 4-O-methyl-D-glucurono-D-xylan, but not PNP-cellobiopyranoside and 4-nitrophenyl-acetate (Table 3). These results are in contrast to the usual characteristics of $\beta$-D-xylosidase, which are very specific for xylopyranosides, while the more unspecific $\beta$-D-glucosidases act both on PNP-glu and PNPxyl (Peralta et al. 1997; Iwashita et al. 1998; Kimura et al. 1999).

In relation to the hydrolysis of the natural substrates, xylobiose was the favorite substrate for $\beta$-xylosidase. However, the enzyme was able to hydrolyze xylan of different sources, as birchwood xylan, larchwood xylan, oat spelt xylan and eucalyptus xylan, respectively (Table 4), which is in contrast to the properties of true $\beta$-xylosidases.

Table 3 Hydrolysis of synthetic substrates by A. ochraceus $\beta$ xylosidase

\begin{tabular}{ll}
\hline Synthetic substrates & $\%$ \\
\hline$p$-nitrophenyl- $\beta$-D-xylopyranoside & 100.00 \\
$p$-nitrophenyl- $\beta$-D-glucopyranoside & 53.95 \\
$p$-nitrophenyl- $\beta$-D-arabinopyranoside & 10.53 \\
$p$-nitrophenyl- $\beta$-D-galactopyranoside & 7.89 \\
$p$-nitrophenyl- $\beta$-D-cellobiopyranoside & nd \\
4-O-methyl-D-glucurono-D-xylan & 1.32 \\
4-nitrophenyl-acetate & nd \\
\hline
\end{tabular}

nd not detected

The assays were performed at $70{ }^{\circ} \mathrm{C}$ and $\mathrm{pH} 4.5$
Table 4 Hydrolysis of natural substrates by A. ochraceus $\beta$ xylosidase

\begin{tabular}{lr}
\hline Natural substrates & \multicolumn{1}{c}{$\%$} \\
\hline Xylobiose & 100.00 \\
Birchwood xylan & 13.11 \\
Larchwood xylan & 6.89 \\
Oat spelt xylan & 5.57 \\
Eucalyptus xylan & 2.30 \\
\hline
\end{tabular}

The assays were performed at $70^{\circ} \mathrm{C}$ and $\mathrm{pH} 4.5$

Xylans are heteropolysaccharides constituted by a main backbone of xylose residues with distinct degree of substituents according to the origin of plant. These substituents can include acetyl groups, 4- $O$-methyl- $\alpha$-D-glucuronopyranosyl units and $\alpha$-L-arabinofuranosyl groups (Polizeli 2009). The knowledge of the xylans composition from different sources may explain the differences in specificity observed for the $\beta$-xylosidase.

Birchwood xylan presented the highest content of xylose $(89.1 \%)$, and it was xylan which had higher affinity by the enzyme. Oat spelt xylan, besides the high xylose content $(65.2 \%)$, also showed a high content of arabinose $(20.1 \%)$. This is according to the literature, since arabinoxylans have been identified in wheat, rye, barley, oat, rice and sorghum (Polizeli et al. 2005). Similar composition was reported by $\mathrm{Li}$ et al. (2000). They reported that larchwood xylan presents in its constitution high content of mannose $(26 \%)$ and glucose $(26.5 \%)$ besides xylose (47.5\%). The A. ochraceus $\beta$-xylosidase hydrolyzed oat spelt xylan and larchwood xylan in similar degree. However, eucalyptus xylan showed the smallest hydrolysis rate, and its composition proved to be the most complex among the xylans and besides the high content of xylose $(63 \%)$, it also presented a high content of acetic acid (16\%), showing to be an acetylated xylan (Table 5).

Table 5 Chemical compositions of the xylans

\begin{tabular}{|c|c|c|c|}
\hline & \multicolumn{3}{|c|}{ Carbohydrate residues (molar \%) } \\
\hline & $\begin{array}{l}\text { Birchwood } \\
\text { xylan }\end{array}$ & $\begin{array}{l}\text { Oat spelt } \\
\text { xylan }\end{array}$ & $\begin{array}{l}\text { Eucalyptus } \\
\text { xylan }\end{array}$ \\
\hline Arabinose & nd & 20.10 & 0.75 \\
\hline Glucose & 2.35 & 5.95 & 3.25 \\
\hline Galactose & 8.56 & 6.94 & 7.95 \\
\hline Xylose & 89.09 & 65.21 & 62.70 \\
\hline Mannose & nd & nd & 9.35 \\
\hline $\begin{array}{l}\text { Galacturonic } \\
\text { acid }\end{array}$ & nd & nd & 0.25 \\
\hline Acetic acid & nd & 1.80 & 15.75 \\
\hline
\end{tabular}

$n d$ not detected 
Fig. 4 Thin layer chromatography of the hydrolysis products of xylooligosaccharides (a) and xylan (b) by the purified $\beta$-Dxylosidase. Hydrolysis times were $0,15,30,60,120$ and $360 \mathrm{~min}$. Standards $(\mathrm{S})$ were a mixture of $1 \mathrm{mg} \mathrm{ml}^{-1}$ of xylose $\left(\mathrm{X}_{1}\right)$ and xylobiose $\left(\mathrm{X}_{2}\right)$. The assays were performed at $70{ }^{\circ} \mathrm{C}$ and $\mathrm{pH} 4.5$

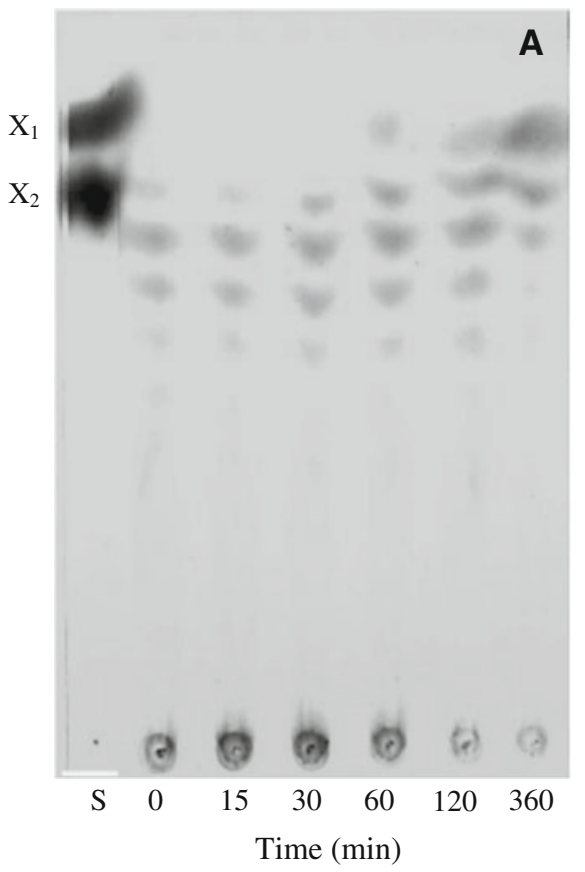

Kinetic parameters

The purified enzyme exhibited a typical Michaelis-Menten kinetics, with $\mathrm{K}_{\mathrm{m}}$ and $\mathrm{V}_{\max }$ values for $p$-NP-xyl of $0.66 \mathrm{mM}$ and $39 \mathrm{U}$ (mg protein $)^{-1}$, respectively. This $\mathrm{K}_{\mathrm{m}}$ value suggests higher affinity for $p$-NP-xyl for the $\beta$-xylosidase from $A$. ochraceus than that reported to T. thermophilus (Guerfali et al. 2008), Scytalidium thermophilum (Zanoelo et al. 2004) and Aspergillus phoenicis (Rizzatti et al. 2001).

Analysis of the hydrolysis products

Thin layer chromatography of the products resulting from the action of $A$. ochraceus purified $\beta$-D-xylosidase on xylooligosaccharides mixtures showed that the enzyme hydrolyzed these substrates until xylopentaose. It is possible be observed a reduction and/or disappearance in the concentration of large xylo-oligosaccharides, such as xylopentaose and xylotetraose, after $6 \mathrm{~h}$; and an increase of smaller xylo-oligosaccharides, as xylobiose and xylose, as a consequence of these hydrolysis (Fig. 4a).

The A. phoenicis $\beta$-xylosidase hydrolyzed only up to xylotriose (Rizzatti et al. 2001), while the S. thermophilum $\beta$-xylosidase hydrolyzed up to xylotetraose (Zanoelo et al. 2004 ) and Fusarium proliferatum $\beta$-xylosidase hydrolyzed up to xylohexaose (Saha 2003b). According to Yan et al. (2008), $\beta$-xylosidases that hydrolyze up to xylopentose seem to be more applicable for xylan saccharifications.

Then, true $\beta$-D-xylosidases release xylose from xylobiose and xylo-oligosaccharides, a typical feature of an exo-type xylanolytic enzyme (Herrmann et al. 1997). However, the
A. ochraceus $\beta$-xylosidase is able to release xylose from xylan (Fig. 4b), confirming the exo-character of the enzyme and showing a novel $\beta$-xylosidase that is able to hydrolyze xylan besides xylobiose and short xylo-oligosaccharides.

Acknowledgments This work was supported by the Fundação de Amparo à Pesquisa do Estado de São Paulo (FAPESP), and the Conselho de Desenvolvimento Científico e Tecnológico (CNPq). J. A. J. and M. L. T. M. P are Research Fellows of CNPq. M. M. was a recipient of a FAPESP fellowship and this work is part of her Doctoral Thesis. It is also part of the project SISBIOTA CNPq: 563260/2010-6 and FAPESP: 2010/52322-3. We thank Ricardo Alarcon and Maurício de Oliveira for technical assistance and Mariana Cereia for language revision.

\section{References}

Betini JHA, Michelin M, Peixoto-Nogueira SC, Jorge JA, Terenzi HF, Polizeli MLTM (2009) Xylanases from Aspergillus niger, Aspergillus niveus and Aspergillus ochraceus produced under solid-state fermentation and their application in cellulose pulp bleaching. Bioprocess Biosyst Eng 32:819-824

Biely P (1985) Microbial xylanolytic systems. Trends Biotechnol 3: 286-290

Biely P (1993) Biochemical aspects of the production of microbial hemicellulases. In: Coughlan MP, Hazlewood GP (eds) Hemicellulose and hemicellulases. Portland Press, London, pp 29-51

Davis BJ (1964) Disc electrophoresis: II. Methods and application to human serum proteins. Ann NY Acad Sci 121:404-427

Dubois M, Gilles KA, Hamilton JK, Rebers PA, Smith F (1956) Colorimetric method for determination of sugars and related substances. Anal Chem 28:350-356

Eriksson K-E, Wood TM (1985) Biodegradation of cellulose. In: Higuchi $\mathrm{T}$ (ed) Biosynthesis and biodegradation of wood components. Academic Press, New York, pp 469-503

Fontana JD, Gebara M, Blumel M, Schneider H, Mackenzie CR, Johnson KG (1988) $\alpha$-4-O-methyl-D-glucuronidase component of xylanolytic complexes. Methods Enzymol 160:560-571 
Guerfali M, Gargouri A, Belghith H (2008) Talaromyces thermophilus $\beta$-D-xylosidase: purification, characterization and xylobiose synthesis. Appl Biochem Biotechnol 150:267-279

Herrmann MC, Vrsanska M, Jurickova M, Hirsch J, Biely P, Kubicek CP (1997) The $\beta$-D-xylosidase of Trichoderma ressei is a multifunctional $\beta$-D-xylan xylohydrolase. Biochem J 321: 375-381

Iwashita K, Todoroki K, Kimura H, Shimoi H, Ito K (1998) Purification and characterization of extracellular and cell wall bound $\beta$-glucosidases from Aspergillus kawachii. Biosci Biotechnol Biochem 62:1938-1946

Kimura I, Yoshioka N, Tajima S (1999) Purification and characterization of a $\beta$-glucosidase with $\beta$-xylosidase activity from Aspergillus sojae. J Biosc Bioeng 87:538-541

Knob A, Terrasan CRF, Carmona EC (2010) $\beta$-Xylosidases from filamentous fungi: an overview. World J Microbiol Biotechnol 26:389-407

Kulkarni N, Shendye A, Rao M (1999) Molecular and biotechnological aspects of xylanases. FEMS Microbiol Rev 23:411-456

Kurakabe M, Osada S, Komaki T (1997) Transglycosylation of $\beta$ xylosidase from Aspergillus awamori K4. Biosci Biotechnol Biochem 61:2010-2014

Laemmli UK (1970) Cleavage of structural proteins during the assembly of head of bacteriophage T4. Nature 227:680-685

Lenartovicz V, de Souza CGM, Moreira FG, Peralta RM (2003) Temperature and carbon source affect the production and secretion of thermostable $\beta$-xylosidase by Aspergillus fumigatus. Process Biochem 38:1775-1780

Li K, Azadi P, Collins R, Tolan J, Kim JS, Eriksson K-EL (2000) Relationships between activities of xylanases and xylan structures. Enz Microbial Technol 27:89-94

Lineweaver H, Burk D (1934) The determination of the enzyme dissociation. J Am Chem Soc 56:658-666

Lowry OH, Rosebrough NJ, Farr AL, Randall RJ (1951) Protein measurement with the folin phenol reagent. J Biol Chem 193:267-275

Michelin M, Peixoto-Nogueira SC, Betini JHA, Silva TM, Jorge JA, Terenzi HF, Polizeli MLTM (2010) Production and properties of xylanases from Aspergillus terricola Marchal and Aspergillus ochraceus and their use in cellulose pulp bleaching. Bioprocess Biosyst Eng 33:813-821

Miller GH (1959) Use of dinitrosalicylic acid reagent for determination of reducing sugar. Anal Chem 31:426-429

Peralta RM, Kadowaki MK, Terenzi HF, Jorge JA (1997) A highly thermostable $\beta$-glucosidase activity from thermophilic fungus Humicola grisea var. thermoidea: purification and biochemical characterization. FEMS Microbiol Lett 146:291-295

Polizeli MLTM (2009) Properties and commercial applications of xylanases from fungi. In: Rai $M$ (ed) Advances in fungal biotechnology. IK International Publisher, New Delhi, pp 82-108

Polizeli MLTM, Rizzatti ACS, Monti R, Terenzi HF, Jorge JA, Amorim DS (2005) Xylanases from fungi: properties and industrial applications. Appl Microbiol Biotechnol 67:577-591

Poutanen K, Puls J (1988) Characteristics of Trichoderma reesei $\beta$ xylosidase and its use in hydrolysis of solubilized xylans. Appl Microbiol Biotechnol 28:425-432
Rasmussem LE, Sorensen HR, Vind J, Vikso-Nielsen A (2006) Mode of action and properties of the $\beta$-xylosidase from Talaromyces emersonii and Trichoderma reesei. Biotechnol Bioeng 94:869-876

Rizzatti ACS, Jorge JA, Terenzi HF, Rechia CGV, Polizeli MLTM (2001) Purification and properties of a thermostable extracellular $\beta$-D-xylosidase produced by a thermotolerant Aspergillus phoenicis. J Ind Microbiol Biotechnol 26:156-160

Ruzene DS, Silva DP, Vicente AA, Gonçalves AR, Teixeira JA (2008) An alternative application to the Portuguese agroindustrial residue: wheat straw. Appl Biochem Biotechnol 147: $85-96$

Saha BC (2003a) Hemicellulose bioconversion. J Ind Microbiol Biotechnol 30:279-291

Saha BC (2003b) Purification and properties of an extracellular betaxylosidase from a newly isolated Fusarium proliferatum. Biores Technol 90:33-38

Saha BC, Bothast RJ (1999) Enzymology of xylan degradation. In: Imam SH, Greene RV, Zaidi BR (eds) Biopolymers: utilizing nature's advanced materials. ACS Symposium Series 723, Washington, DC, pp 167-194

Sandrim VC, Rizzatti ACS, Terenzi HF, Jorge JA, Milagres AMF, Polizeli MLTM (2005) Purification and biochemical characterization of two xylanases produced by Aspergillus caespitosus and their potential for kraft pulp bleaching. Process Biochem 40:1823-1828

Sunna A, Antranikian G (1997) Xylanolytic enzymes from fungi and bacteria. Crit Rev Biotechnol 17:39-67

Viikari L, Kantelinen A, Sundquist J, Linko M (1994) Xylanases in bleaching: from an idea to the industry. FEMS Microbiol Rev 13:335-350

Wakiyama M, Yoshihara K, Hayashi S, Ohta K (2008) Purification and properties of an extracellular $\beta$-xylosidase from Aspergillus japonicus and sequence analysis of the encoding gene. J Biosci Bioeng 106(4):398-404

Wiseman A (1975) Handbook of enzyme biotechnology. Wiley, London, p 148

Wong KKY, Saddler JN (1993) Applications of hemicellulases in the food, feed and pulp and paper industries. In: Coughlan MP, Hazlewood GP (eds) Hemicelluloses and hemicellulases. Portland Press, London, pp 127-143

Wong KKY, Tan LUL, Saddler JN (1988) Multiplicity of $\beta$-1,4xylanase in Microorganisms: functions and Applications. Microbiol Rev 53:305-317

Ximenes FA, Silveira FQP, Filho EXF (1996) Production of $\beta$ xylosidase activity by Trichoderma harzianum strains. Curr Microbiol 33:71-77

Yan QJ, Wang L, Jiang ZQ, Yang SQ, Zhu HF, Li LT (2008) A xylose-tolerant $\beta$-xylosidase from Paecilomyces thermophila: characterization and its co-action with the endogeneous xylanase. Biores Technol 99:5402-5410

Zamost BL, Nielsen HK, Starnes RL (1991) Thermostable enzymes for industrial applications. J Ind Microbiol Biotechnol 8:71-82

Zanoelo FF, Polizeli MLTM, Terenzi HF, Jorge JA (2004) Purification and biochemical properties of a thermostable xylose-tolerant $\beta$-D-xylosidase from Scytalidium thermophilum. J Ind Microbiol Biotechnol 31:170-176 